学イメージング委員会より出された “SPECT 装置の性 能試験条件”に基づいて行ったので報告する。

使用核種は ${ }^{99 \mathrm{~m}} \mathrm{Tc}$, 再構成画像処理は Butterworth filter, Ramachandler HR-cut off $15 \mathrm{~mm}$ で行った.ま た，使用した Phantom は $20 \mathrm{~cm}$ 径である.

〔結果〕高分解能コリメータ HR 使用時において空 間分解能は視野中心で $11.4 \mathrm{~mm}$, 中心から $70 \mathrm{~mm}$ の位置 で, $10.3 \mathrm{~mm}$ ，スライス厚, $15.0 \mathrm{~mm}$ ，システム感度 は, $5.2 \mathrm{kcps} / \mu \mathrm{ci} / \mathrm{ml}$, 均一性は変動值 CV が5.0以下で ある。濃度分解能，濃度直線性とも良好。サイズ依存性 はないが, 位置依存性が大きい.

〔考察〕今回の性能評価は SPECT 装置の性能試験条 件に基づいているがトンネル径の小さいリング型 SPECT 装置では条件に一致しない傾向もあり，今後り ング型 SPECT 装置に適用可能な観告の考慮が望まれる。

\section{SPECT 装置の性能評価}

\section{市立札幌病院 ○外田 稔}

近年, ガンマカメラの検出器を回転型にした SPECT 装置の普及が目ざましい. SPECT 装置を効果的に使用 するためには，装置の性能について十分理解していなけ ればならない。また SPECT の画質の評価によって，定 期的な性能の点検としても利用できる.

そこで，今回，性能測定専用のファントムを使用する 機会があり, SPECT 画像における濃度均一性, 濃度直線 性, スライスの厚さ, 空間分解能のそれぞれについて, 汎用型コリメータと高分解能コリメータとを, 比較検討 を行った．また，画像再構成におけるフィルタの違いに よる画像への影響についても調べた。

\section{SPECT における画像改善フィルタの検討}

\section{砂川市立病院放射線科}

○飯田 哲・後藤利昭・森井秀俊

核医学検査における SPECT は，時間的制約，被検者 との距離, 検出器個有の一様性の德さ，等により情報量 が少なく, 解像力も悪くなる.したがって $\mathrm{S} / \mathrm{N}$ 比は極度 に悪化し効果的使用に対し画像再成前に復元フィル夕を 使用し画像の改善について検討した。

検討したフィルタはウィナーフィルタとバターワース フィルタである.ウィナーフィル夕は $\mathrm{Pm} / \mathrm{Pf}$ $0.1 \sim 0.2, \mathrm{~m}$ (半值巾) $2 \sim 3$ ピクセルと変化させた. バターワースフィル夕は, fc (遮断周波数) $0.1 \sim 0.4$ まで 次数 $n$ を 9 次までとしてファントム実験と臨床画 像で検討を加え, ウィナーフィルタで Pn/Pf 0.1， $m=$ 2 ，または 3 が最も診断価値の高い画像となった。
17. (P, 5n) 反応による IMP の画像収集条件と 5 時間 後画像の意義について

\section{砂川市立病院放射線科}

○後藤利昭・森井秀俊・飯田 哲

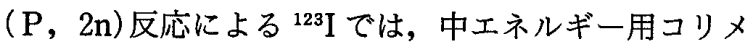
一夕を使用していたが，(P，5n)反応による ${ }^{123} I$ は低工 ネルギー用コリメータが使用可能となり, 解剖学的にす ぐれた画像が得られる。また 5 時間後の画像で正常例は， early image で高い集積を示した小脳および後頭の部位 が，相対的に集積低下を示す．また白質部分は，delayed imageで集積が上昇する，脳虚血疾患例では，early image で血流が低下している部位に 5 時間後に集積さ れる例が多くみられた。そのような例は，神経学的所見 および文献的考察によると，何らかの脳代謝と関連を持 ち, 脳組織の生物学的活性の程度を 5 時間後の画像が表 現していると思われた。

\section{座長集約}

演題14,15に関しては画像の性能評価, 同一内容のも ので，空間分解能，スライス厚，均一性，濃度分解能と 直線性，位置依存性，サイズ依存性の発表である。

核医学イメージング規格化専門委員会からの提示され た ECT 装置の性能試験条件に基づいた画質評価である。

演題15についてはコリメータ, 汎用型と高分解能型の 比較および画像再構成時によるフィルタの変化による性 能評価の比較検討がされた。

これ等の実験は装置購入時には性能評価を十分知って おく必要があり，今後の保守管理に十分役立つことと思 う.

演題16に関しては.SPECT による画像改善フィルタの 検討で情報量の少ない収集条件でも画像再構成の処理前 にフィルタを使用することで診断可能な画像を作ること の報告である。

質問 バターウオスフィルタとウィナーフィルタの 1 枚当りの処理時間はどの位か。（札幌市立，外田）

答 バターウォスフィル夕は 8 秒で, ウィナーフィル 夕は 5 秒（砂川市立，飯田）

質問 フィルタをホットとコールドの画像での使い分 けはしているか。(中村記念，山岸）

答 使い分けはしていない.（砂川市立，飯田）

演題17に関しては，従来の $(\mathrm{P}, 2 \mathrm{n})$ 反応と $(\mathrm{P}, 5 \mathrm{n})$

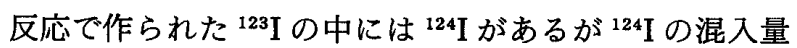
の検討で低エネルギー, コリメータ使用が報告された。

質問 低エネルギーコリメータのエネルギーは何 $\mathrm{keV}$ まで対応するか. (座長) 